\title{
Transfer of a foreign gene to Japanese abalone (Haliotis diversicolor supertexta) by direct testis-injection
}

\author{
Hsin-Liang Chen ${ }^{\mathrm{a}}$, Hong-Shii Yang ${ }^{\mathrm{b}}$, Rang Huang ${ }^{\mathrm{a}}$, Huai-Jen Tsai ${ }^{\mathrm{c}, *}$ \\ ${ }^{a}$ Institute of Oceanography, National Taiwan University, Taipei, 106, Taiwan \\ ${ }^{\mathrm{b}}$ Mariculture Research Center of the Fisheries Research Institute, Tainan, 724, Taiwan \\ ${ }^{\mathrm{c}}$ Institute of Molecular and Cellular Biology, National Taiwan University, Taipei, 106, Taiwan
}

Received 6 August 2004; received in revised form 19 September 2005; accepted 25 September 2005

\begin{abstract}
We developed a technique that easily transfers exogenous DNA fragments into the genome of Japanese abalone (Haliotis diversicolor supertexta), an important aquaculture shellfish. From 0.1 to $10 \mu \mathrm{g} / \mu \mathrm{l}$ of the linearized plasmid pOBA-YPGHc, containing the yellowfin porgy (Acanthopagrus latus) growth hormone cDNA driven by the medaka $\beta$-actin promoter, was directly injected into abalone testis with a microsyringe in a total volume of $10 \mu \mathrm{l}$. The sperm activity, fertility, and hatchability of fertilized eggs from testis-injected abalone did not differ $(P<0.05)$ from those of abalone in the untreated control group. From extracted genomic DNA from sperm, larvae at the trochophore stage ( $9 \mathrm{~h}$ after fertilization), juveniles ( 3 weeks after fertilization), and adults (1-year-old) of testis-injected abalone, a product with a molecular weight of 954-bp was amplified using polymerase chain reaction (PCR). Southern blot analysis showed that the amplified PCR product hybridized to the pOBA-YPGHc probe. The gene-transfer efficiency of $\mathrm{G}_{0}$ in larvae, juveniles, and 1-year-old adults was $90 \%, 92.5 \%$, and $60 \%$, respectively. Around $20 \%$ of $\mathrm{G}_{0}$ mature abalone contained the transgene in their gonads. Genomic Southern blot analysis of 1-year-old abalone derived from DNA-injected group revealed that the transgene was integrated in the genome of the transgenic abalone. The mean shell lengths and body weights were significantly greater $(P<0.05)$ than those of control group. We conclude that direct testis injection is a simple, highthroughput, minimally invasive, non-viral based, and efficient approach for producing transgenic abalone.
\end{abstract}

(C) 2005 Elsevier B.V. All rights reserved.

Keywords: Abalone; Gene transfer; Testis; Injection

\section{Introduction}

Transgenic animals provide a powerful system for in vivo study of gene regulation, expression, and function. Transgenics make it possible to generate varieties with special genetic traits encoded by specific genes and to produce mutants with a particular

\footnotetext{
* Corresponding author. No. 1, Section 4, Roosevelt Road, Taipei, 106, Taiwan. Tel.: +88622364 1705; fax: +886223638483.

E-mail address: hjtsai@ntu.edu.tw (H.-J. Tsai).
}

defective gene. Gene delivery to aquatic animals, including commercially important species of finfish and shellfish, has been studied for more than 20 years (reviewed by Gong and Hew, 1995; Sin, 1997). Many approaches have been developed to introduce foreign DNA molecules into gametes or embryos. In finfishes, microinjection is the most common method for transferring the foreign DNA into oocyte nuclei (Ozato et al., 1986; Tsai et al., 1995b), cytoplasm of developing embryos (Chourrout et al., 1986; Dunham et al., 1987) and fertilized eggs (Fletcher et al., 1988; 
Dunham et al., 1992; Lu et al., 1992). Electroporation of exogenous DNA fragments into fertilized eggs (Inoue et al., 1990; Powers et al., 1992; Tsai and Tseng, 1994) is rather simple, convenient, and more efficient than microinjection. In shellfishes, genes have been transferred by electroporation of red abalone (Haliotis rufescens) embryos (Powers et al., 1995), retroviral infection for dwarf surf clams (Mulina lateralis) ( $\mathrm{Lu}$ et al., 1996), particle bombardment for Pacific oyster (Crassostrea gigas) (Cadoret et al., 1997a), and microinjection, electroporation or chemical-mediated transfection of embryos for Eastern oyster (C. virginica) (Cadoret et al., 1997b; Buchanan et al., 2001). In the above studies there was no documentation of transgene integration or inheritance except reported in dwarf surf clams. However, those methods for transferring genes to fertilized eggs are insufficient for quickly treating the tremendously large number of eggs spawned by cultured species of shellfishes.

Aquatic animals produce huge numbers of sperm, which are excellent material for gene transfer because the sperm-mediated method is considered a mass gene transfer technique, sperm can deliver foreign DNA fragments into the nucleus, and sperm can be kept by cryopreservation (reviewed by Tsai, 2000; Li and Tsai, 2000). Such advantages make sperm a potentially useful vector to introduce foreign DNA and produce transgenic finfish and shellfish. Genes have been transferred by sperm-incubation in zebrafish (Khoo et al., 1992), sperm-electroporation in common carp (Cyprinus carpioL.) (Muller et al., 1992), catfish (Clarias gariepinus) (Muller et al., 1992), tilapia (Oreochromis niloticus) (Muller et al., 1992), chinook salmon (Oncorhynchus tshawytscha) (Symonds et al., 1994), loach (Misgurnus anguillicaudatus) (Tsai et al., 1995a), and Japanese small abalone (H. diversicolor supertexta) (Tsai et al., 1997). However, all these methods still have limitations: (1) the facilities required for sperm-mediated gene transfer are expensive; (2) culturing $\mathrm{G}_{0}$ individuals to reach adulthood is absolutely required before the transgenic founders that enable to transmit the transgene to offspring are identified; and (3) DNA preparation and gamete induction are time-consuming and tedious, especially for abalone, making this method impossible for use in field trials.

The testis of an abalone is easily accessible, because the gonad is exposed when one holds its shell. In this paper, we describe a method of injecting foreign DNA fragments with an all-fish-construct directly into the testis of abalone to achieve faster growth, and de- monstrate that this approach is the simplest and mostefficient method for gene transfer for large numbers of abalone.

\section{Materials and methods}

\subsection{Experimental animals}

Male and female 2- to 3-year-old, aquacultured Japanese small abalone were cultured in two separate 20 1 containers and maintained in 101 of natural seawater treated with Millipore filtration and ultraviolet light irradiation. The 39 males and 20 females were kept on a natural daylight cycle in a temperature-controlled $\left(25{ }^{\circ} \mathrm{C}, 30 \%\right.$ ) container without feeding during the period of ovulation or spermiation. Males averaged $5.7 \pm 0.2 \mathrm{~cm}$ in length, $4.6 \pm 0.3 \mathrm{~cm}$ in width, and $29.3 \pm$ $1.4 \mathrm{~g}$ in weight. Females averaged $6.1 \pm 0.3 \mathrm{~cm}$ in length, $4.9 \pm 0.1 \mathrm{~cm}$ in width, and $31.6 \pm 1.9 \mathrm{~g}$ in weight.

\subsection{DNA preparation}

Expression vector, pOBA-YPGHc, with a molecular weight of $8 \mathrm{~kb}$, consists of a medaka (Oryzias latipes) $\beta$ actin gene promoter (OBA; Takagi et al., 1994) and a yellowfin porgy (Acanthopagrus latus) growth hormone cDNA (YPGHc; Tsai et al., 1993). This plasmid was produced at large scale, as described by Sambrook et al. (1989), extracted by using the VIOGENE V500 kit (VIOGENE, Sunnyvale, CA, U.S.A.), digested by NsiI, and isolated by a gel-recovery kit (Geneaid, Taipei, Taiwan). The purified linear DNA plasmid was resuspended in filtered sterilized seawater at concentrations of 0.1 or $10 \mu \mathrm{g} / \mu \mathrm{l}$.

\subsection{Testis injection}

Foreign DNA, at concentrations of 0.1 or $10 \mu \mathrm{g} / \mu \mathrm{l}$ in a total volume of $10 \mu \mathrm{l}$, was directly injected into the posterior part of the testis of abalone with a microsyringe (Hamilton, Reno, NV, U.S.A.) for testing whether the injection affected milt production. For the mock-treatment control group, filtered (sterilized) seawater was used instead, and two abalone were used for each group. Subsequently, we injected 0.1 and 10 $\mu \mathrm{g} / \mu \mathrm{l}$ foreign DNA fragments (three abalone for each concentration) into the anterior, middle, and posterior part of the testis ( $N=18$ for transgene-injections, $N=9$ for mock-treatment overall) to determine whether the successful gene-transfer rate is dependent on the side of injection. After injection, abalone were cultured in a 
temperature-controlled $\left(28{ }^{\circ} \mathrm{C}\right)$ container for $3-6$ $\mathrm{h}$ before they produced milt.

\subsection{Gamete collection, sperm mobility and in vitro fertilization}

Six, matured male abalone were divided into three groups: one mock-treatment group and two experimental groups $(0.1$ and $10 \mu \mathrm{g} / \mu \mathrm{l}$ foreign DNA). Each group was maintained separately in a 101 container with natural seawater. Twenty mature female abalone were maintained in a 301 container. The temperature-shift method was used to induce ovulation or milt production (Chen and Yang, 1979). Sperm from two males in each group were collected and kept in a 11 glass container. The number of gametes obtained was estimated using a hemocytometer slide. Sperm mobility evaluation and in vitro fertilization were described previously (Tsai et al., 1997).

\subsection{Fertilization and hatching rates}

The fertilization rate was the proportion of eggs that developed into the two-cell or four-cell stage $1 \mathrm{~h}$ after fertilization. The hatching rate was the proportion of fertilized eggs that developed into the trochophore stage (9 $\mathrm{h}$ after fertilization).

\subsection{DNase I treatment and genomic DNA extraction}

Sperm or larvae were pooled, collected in a $1.5-\mathrm{ml}$ Eppendorf tube, and preserved with 100\% ethanol. Prior to extraction, the samples were centrifuged at $8000 \times g$ for $5 \mathrm{~min}$, the ethanol was removed, seawater was added to wash the pellet three times, and the pellet was resuspended in $500 \mu \mathrm{l}$ of digestion buffer. To ensure PCR detection of the foreign DNA molecules in the sperm and trochophore larvae and to avoid contamination with non-integrated DNA fragments, DNase I (Sigma, St. Louis, MO, U.S.A.) was added to a final concentration of $100 \mu \mathrm{g} / \mathrm{ml}$ and used to wash samples from each treatment group. The solution was incubated at $37^{\circ} \mathrm{C}$ for $1 \mathrm{~h}$. After the reaction, the samples were centrifuged at $8000 \times g$ for $5 \mathrm{~min}$. The supernatant was decanted, and samples were boiled for $10 \mathrm{~min}$ to halt DNase activity.

Genomic DNA was extracted from sperm $\left(10^{10}\right.$ cells); 1, 10, 25, 50 trochophore larvae; a 3-week-old juvenile; and a 1-year-old adult by adding $200 \mu \mathrm{l}$ of lysis solution (6 M guanidine hydrochloride and 0.1 $\mathrm{M}$ sodium acetate, $\mathrm{pH}$ 5.5). Samples were crushed quickly and then incubated at room temperature for
$3 \mathrm{~h}$ on a rotating platform. The genomic DNA was obtained by phenol/chloroform extraction and ethanol precipitation.

\subsection{PCR analysis}

Two oligonucleotide primers were synthesized for detection of YPGH cDNA by PCR analysis: forward primer (5'-GGTCCCTTTGTGCGCCGTTA-3') and reverse primer $\left(5^{\prime}\right.$-CTGTCGTTGCTCCTCAGTCAG$\left.3^{\prime}\right)$. The primers for detection of the endogenous $\beta$ tubulin gene, which served as an internal control, were forward primer (5'-CCCTTCCCTCGTCTCCAC- $\left.3^{\prime}\right)$ and reverse primer (5'-GCCAGTGTACCAGTGAAGGGA-3'). Each PCR sample consisted of $20 \mu \mathrm{l}$ of solution containing 10-20 ng of template, 10 pmol of each primer, $25 \mu \mathrm{M}$ of each dNTP, and 5 units of ProZyme II (PROtech, Taipei, Taiwan), in a $10 \times$ PCR buffer. Amplification was performed with a Perkin-Elmer Cetus DNA Thermal Cycler (Boston, MA, U.S.A.). PCR consisted of 25 cycles of denaturation at $94{ }^{\circ} \mathrm{C}$ for $1 \mathrm{~min}$, annealing at $60{ }^{\circ} \mathrm{C}$ for $1 \mathrm{~min}$, and extension at $72{ }^{\circ} \mathrm{C}$ for $1 \mathrm{~min}$, followed by 10 min extension at $72{ }^{\circ} \mathrm{C}$. Each PCR sample $(10 \mu \mathrm{l})$ was subjected to electrophoresis on a $3 \%$ NuSieve GTG agarose gel (FMC BioProducts, Rockland, ME, U.S.A.).

\subsection{Probe preparation}

The $0.9-\mathrm{kb}$ PCR product containing YPGH cDNA was amplified from plasmid pOBA-YPGHc and purified with a gel-recovery kit. Five micrograms of the 0.9-kb DNA fragments were digoxigenin (DIG)-labeled by the random priming method for $20 \mathrm{~h}$ at $37^{\circ} \mathrm{C}$, as recommended by the manufacturer (Roche, Mannheim, Germany).

\subsection{Southern blot analysis}

PCR products or NsiI-digested genomic DNA were analyzed on an agarose gel and transferred onto a nitrocellulose membrane (Amersham, Little Chalfont, U.K.). After air-drying, the DNA was cross-linked to the membrane by UV irradiation, and then hybridized to the probe of the DIG-labeled YPGHc fragments. Hybridization was carried out overnight, at $42{ }^{\circ} \mathrm{C}$, in a standard buffer solution (Roche, Mannheim, Germany) containing $50 \%$ formamide and $10 \mathrm{ng} / \mathrm{ml}$ of denatured probe. After the membranes were washed, colorimetric detection was carried out with nitroblue tetrazolium and 5-bromo-4-chloro-3-indolyl phosphate reagents, as 
recommended by the manufacturer (Roche, Mannheim, Germany).

\subsection{Gene-transfer efficiency}

The gene-transfer efficiency was the number of PCR-Southern-positive samples divided by the total number of larvae, 3-week-old juveniles, and 1-year-old adults that were examined.

\subsection{Growth performance of abalone after gene transfer}

The transferred DNA fragment, pOBA-YPGHc, encodes the growth hormone of a marine fish under the control of the $\beta$-actin promoter. To infer whether the exogenous DNA fragments are expressed and functional in the transgenic abalone, we studied their growth performance. After a total volume of $10 \mu \mathrm{l}$ of the $10 \mu \mathrm{g} /$ $\mu 1$ DNA fragment was injected into the testes of two parental individuals, we collected sperm and mixed them with eggs that were spawned from six females to carry out in vitro fertilization. After the trochophore stage, all larvae were cultured outdoors in a $1.5 \times 6.0 \mathrm{~m}^{2}$ hatchery pond. Abalone in the control group were cultured under the same conditions but were kept in a different pond adjacent to that of the experimental group. We measured the densities, shell lengths, and body weights of each group from 100 individuals that were haphazardly collected from 10 different places when they were 1-week, 6-months, and 1-year old.

\subsection{Statistical analysis}

The fertilization rate, hatching rate, body lengths, and body weights were analyzed statistically with the general linear models procedure (SAS, Inc., Cary, NC, U.S.A.). A one-way analysis of variance was used to compare the mean values between the mock-treatment and the experimental groups. A Duncan's multiple range test was used to separate sample means. A significance level of $P<0.05$ was used in all statistical analyses.

\section{Results}

\subsection{Effect of injection on sperm activity, fertility, and hatchability}

Our preliminary results showed that there was no difference $(P<0.05)$ in terms of the sperm activity and the number of released sperm $\left(10^{6}\right.$ to $10^{7}$ cells $)$ between the control abalone and the abalone whose testes were injected with sterilized seawater. Then we injected 0 (sterilized seawater) or 0.1 and $10 \mu \mathrm{g} / \mu \mathrm{l}$ foreign DNA in a total volume of $10 \mu 1$ into the posterior part of the testis to evaluate the quality of sperm after milt production was induced. Results showed that there were no significant differences $(P<0.05)$ in both the activity and the number of sperm $\left(10^{6}\right.$ to $10^{7}$ cells $\left./ \mathrm{ml}\right)$ from the treated and the mocktreated abalone.
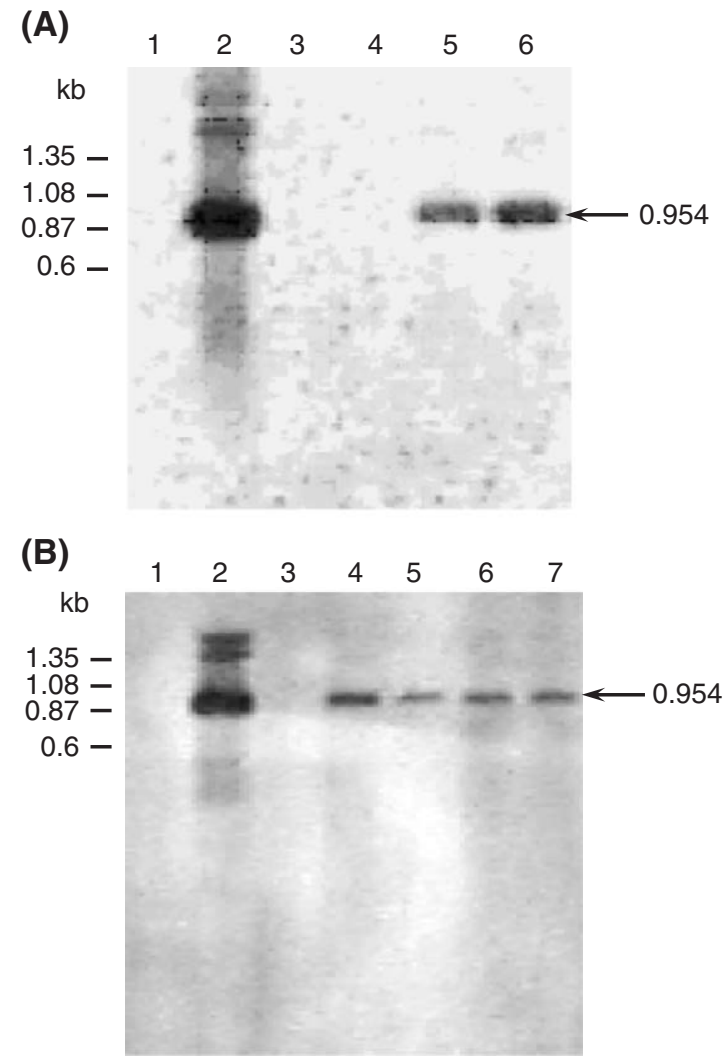

Fig. 1. PCR-Southern blot analysis of genomic DNA isolated from abalone sperm after DNase I treatment (A) and from abalone larvae at the trochophore-stage (B). The purified PCR product of digoxigeninlabeled YPGHc was used as a probe. (A) Lane 1: molecular marker, HaeIII-digested $\varphi \mathrm{X}-174-\mathrm{RF}$ DNA; lane 2: $0.1 \mu \mathrm{g}$ of pOBA-YPGHc as a template (positive control); lane 3: pOBA-YPGHc $(10 \mu \mathrm{g})$ digested with DNase I $(20 \mu \mathrm{g})$ for $2 \mathrm{~h}$; lane 4: sperm from abalone injected with seawater (mock-treatment); lanes 5 and 6: sperm from abalone injected with 0.1 and $10 \mu \mathrm{g}$ of pOBA-YPGHc, respectively, after digestion with DNase I. (B) Lane 1: molecular marker, HaeIIIdigested $\varphi \mathrm{X}-174-\mathrm{RF}$ DNA; lane 2: $0.1 \mu \mathrm{g}$ of pOBA-YPGHc as a template (positive control); lane 3: 50 larvae derived from abalone injected with seawater (mock-treatment); lanes 4, 5, 6, and 7: genomic DNA isolated from 50, 25, 10, and 1 larvae, respectively, derived from abalone injected with $10 \mu \mathrm{g}$ of pOBA-YPGHc. Arrows indicate the PCR product that has the same molecular weight as the control plasmid. 
The fertilization rates of sperm from two of six abalone injected with $10 \mu 1$ of 0.1 or $10 \mu \mathrm{g} / \mu 1$ foreign DNA were $92 \pm 0.6 \%$ and $93 \pm 0.4 \%$, respectively. The rates were not significantly different $(P<0.05)$ from the $95 \pm 0.4 \%$ fertilization rate for mock-treated abalone sperm. The hatching rates were $91 \pm 0.8 \%$ and $90 \pm$ $0.6 \%$, similar to that of the mock-treatment control group at $92 \pm 0.5 \%$.

\subsection{Foreign DNA uptake by sperm}

Ejected sperm $\left(10^{7}\right.$ cells $)$ were collected from individuals subjected to injection of the expression vector into the testis. Regardless of whether the foreign DNA fragments were injected into the anterior, middle, or posterior part of the abalone testis, the same 954-bp PCR product was detected and gave a positive signal in Southern blot analysis (data not shown). Gene-transfer efficiency was unaffected by injection location. For subsequent experiments, 0.1 or $10 \mu \mathrm{g} / \mu \mathrm{l}$ foreign DNA was injected in the middle of the testis. After DNase I digestion, sperm samples were extracted for PCR and Southern blot analyses. A PCR product with a molecular weight of 954-bp was generated. The same product was obtained from the positive control group, for which pOBA-YPGHc was a template (Fig. 1A; lanes 5 and 6).
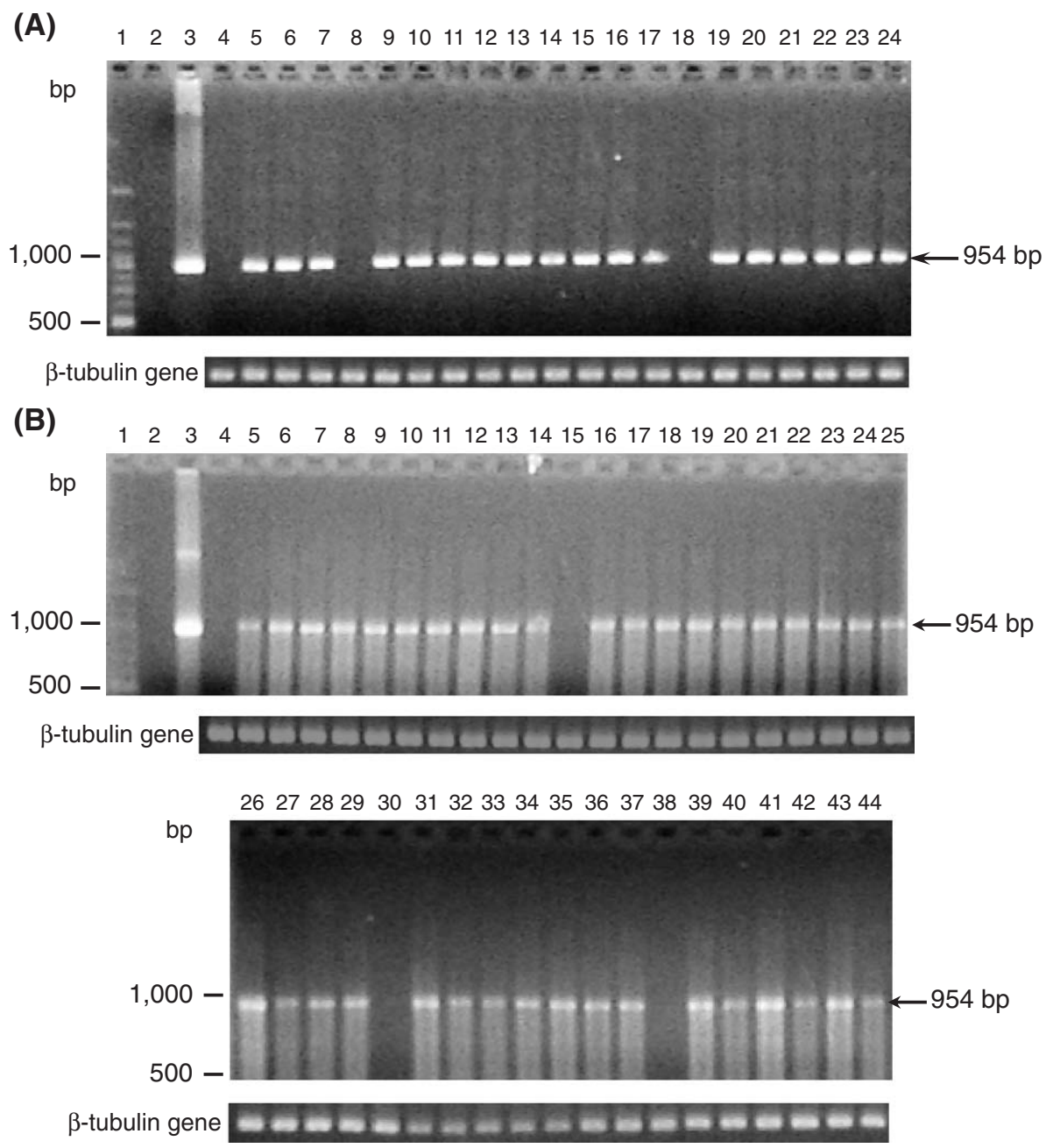

Fig. 2. Use of PCR to detect the transgene and the endogenous $\beta$-tubulin gene in the genomic DNA isolated from a trochophore-stage $\mathrm{G}_{0}$ larva (A) and from a 3-week-old $\mathrm{G}_{0}$ juvenile (B). Lane 1: 100-bp DNA molecular marker; lane 2: no template added (negative control); lane 3: 0.1 $\mu \mathrm{g}$ of pOBA-YPGHc as a template (positive control); lane 4: larva derived from abalone injected with filtered seawater (mock-treatment group); lanes 524 of (A) and lanes 5-44 of (B): derived from founders testis-injected with $10 \mu \mathrm{g}$ of pOBA-YPGHc. The 954-bp PCR product was amplified from the transgene YPGH cDNA as indicated; whereas the 412-bp PCR product shown on the bottom of each lane was amplified from the endogenous $\beta$ tubulin gene (internal control). 
The PCR signal for abalone injected with $10 \mu \mathrm{g} / \mu \mathrm{l}$ foreign DNA was stronger than for abalone injected with $0.1 \mu \mathrm{g} / \mu \mathrm{l}$. Ten micrograms per microliter vector DNA in a total volume of $10 \mu \mathrm{l}$ was used in the subsequent experiments.

\subsection{Analysis of transgenic abalone larvae by PCR- Southern blotting}

Before we could estimate the gene-transfer rate, we needed to determine how many trochophore larvae were required to have sufficient genomic DNA for analyses. We extracted the samples from 1, 10, 25, and 50 larvae in the $10 \mu \mathrm{g} / \mu \mathrm{l}$ treatment group and performed PCR-Southern blot analyses (Fig. 1B). We found that DNA extracted from only one trochophore larva was sufficient for analysis. Results of PCRSouthern blot analyses for 1, 10, and 25 larvae did not differ (Fig. 1B; lanes 5, 6 and 7), except that the signal shown in the group of 50 larvae appeared to have a higher intensity (Fig. 1B; lane 4).

We haphazardly collected 20 trochophore larvae from the $10 \mu \mathrm{g} / \mu \mathrm{l}$ treatment group and performed PCR analysis on their genomes. A single, positive band, with a molecular weight of 954-bp, was observed exclusively in the experimental group (Fig. 2A; lanes 5-24). Based on the appearance of positive signals in the PCR analysis, the rate of gene transfer to abalone larvae was $90 \%$ (18 of 20 larvae examined) using this testisinjection method.
Three weeks after hatching, we haphazardly collected 40 juvenile abalone from the experimental group treated with $10 \mu \mathrm{g} / \mu \mathrm{l}$ foreign DNA. We extracted genomic DNA from each juvenile and performed PCR analysis. A single positive band, as the positive control, with a molecular weight of 954-bp was observed (Fig. 2B; lanes 5-44). In the PCR analysis, positive signals were detected for 37 of 40 juveniles, yielding a genetransfer rate of $92.5 \%$.

After 1 year of culture, we haphazardly collected 10 adults from the $10 \mu \mathrm{g} / \mu \mathrm{l}$ foreign DNA-injection group. Genomic DNA was extracted from three different tissues (muscle, gonad, and others), and PCR analysis was performed. Results showed that positive signal was detected for 8 of 30 samples examined that originated from six individuals. Thus, the gene-transfer rate should be around $60 \%$ ( 6 of 10 abalone). Furthermore, when we detected the transgene in the gonad specifically, gonad cells were isolated directly from the gonad of the 2-yearold $\mathrm{G}_{0}$ abalone and analyzed by PCR. Results showed that $31 \%$ (4 of 13 males) and $33 \%$ (4 of 12 females) of the examined abalone were positive (Fig. 3), suggesting the transgene was carried by the gametes of $\mathrm{G}_{0}$ abalone. After genomic DNA from these eight PCR-positive samples was digested with $N_{s i}$ I (data not shown) and Southern blot analysis was performed, we found positive band(s) with a molecular mass higher than that of the transferred DNA, $8 \mathrm{~kb}$ (Fig. 4; lanes 4-7, 9, and 10), indicating that the transgene was integrated in the host genome. But we noticed that some positive bands

(A)

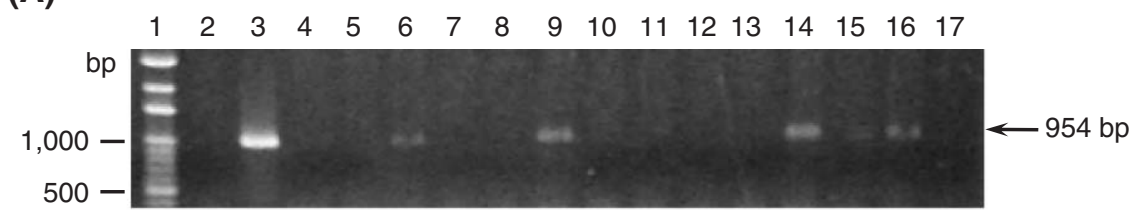

$\beta$-tubulin gene

(B)

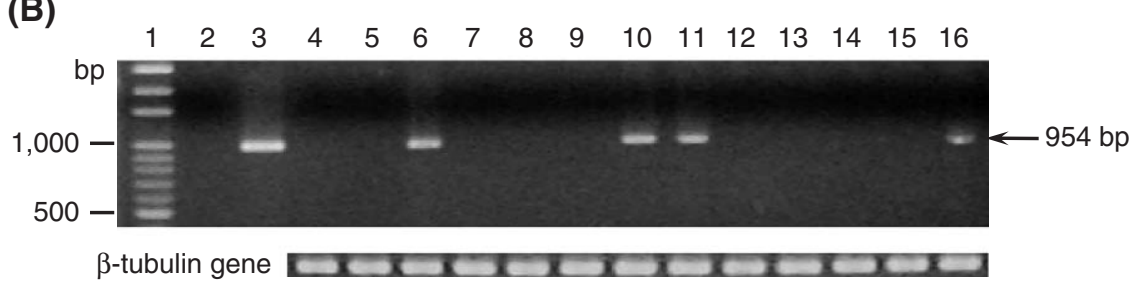

Fig. 3. Use of PCR to detect the transgene DNA fragment in gonad cells of $\mathrm{G}_{0}$ mature abalone. Gonad cells from testis (A) and from ovary (B) were isolated by microsyringe from the gonad of $\mathrm{G}_{0} 2$-year-old abalone derived from founder testis-injected with $10 \mu \mathrm{g}$ of pOBA-YPGHc. Lane 1: 100-bp DNA molecular marker; lane 2; no template added (negative control); lane 3: $0.1 \mu \mathrm{g}$ of pOBA-YPGHc as a template (positive control); lane 4: abalone from mock-treated founder; lanes 5-17 of (A), and lanes 5-16 of (B): individuals from DNA injected founders. The 954-bp PCR product was amplified from the transgene YPGH cDNA as indicated, whereas the 412-bp shown on the bottom was amplified from the endogenous $\beta$-tubulin gene (internal control). 


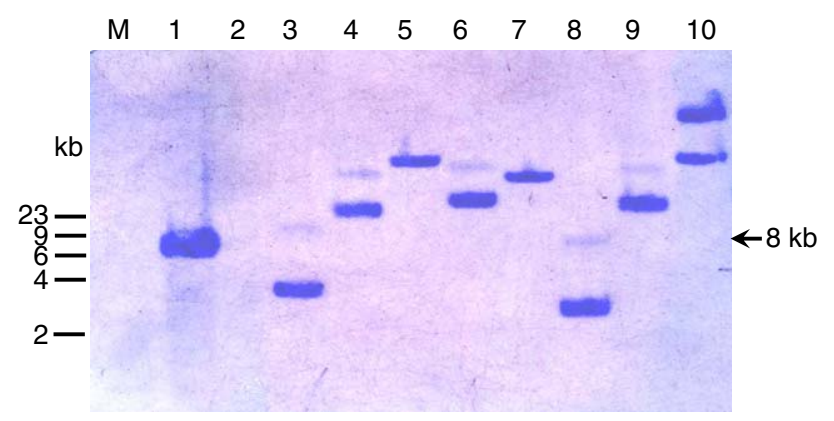

Fig. 4. Southern blot analysis of genomic DNA extracted from 1-year-old abalone derived from founders that were injected with pOBA-YPGHc into the testis. Southern blot analysis was performed by using a digoxigenin-labeled YPGHc as a probe for hybridization. Lane 1: plasmid pOBA-YPGHc used for gene transfer (positive control); lane 2: untreated abalone (negative control); lanes 3-6: muscle from PCR-positive abalone; lanes 7-9: gill and digestive tissues from PCR-positive abalone; lane 10: gonad of PCR-positive abalone. The arrow indicates the molecular size of the linearized transgene $(8.0 \mathrm{~kb})$ fragment.

appeared smaller than $8 \mathrm{~kb}$ (Fig. 4; lanes 3 and 8), suggesting these DNA fragments may be deleted partially.

\subsection{Growth performance of abalone after gene transfer}

As shown in Table 1, there was not much difference between the control group and the DNA-injected group in term of density when they were cultured outdoors in the hatchery ponds for 1 week, 6 months, and 1 year. We randomly collected 100 individuals from each group and found that shell lengths and body weights of abalone from the DNA-injected group were significantly greater than those of abalone from the untreated group at the same stage (Table 1): the DNAinjected group showed an increase $(P<0.05)$ in weight approximately $72.2 \%$ and $81.8 \%$ relative to the control group at 6 months and 1 year, respectively.

\section{Discussion}

Genes have been transferred into abalone by electroporating fertilized eggs (Powers et al., 1995) and sperm (Tsai et al., 1997). However, electroporation requires an expensive electroporator. Processing abalone gametes and performing in vitro fertilization are laborious and time-consuming. In this study, we developed a direct testis-injection system, which is a one-shot, minimally invasive, and high-throughput technique for transferring DNA fragments into the testis of abalone. Neither the instruments of gene transfer nor the preparations of gametes or fertilized eggs are required. The greatest advantage of using direct testis injection is that the gonads of abalone are exposed when one holds the shell. Unlike bivalve mollusks, with abalone, we do not have to force the shells open mechanically. In addition, we found that the fertilization and hatching rates of the experimental and mock-treatment control groups were not significantly different $(P<0.05)$. Therefore, direct injection of DNA fragments in abalone is easy and minimally invasive.

Gene-transfer efficiency is the percentage of embryos, larvae, juveniles, or adults that possess the DNA fragment among the samples examined after treatment. Gene-transfer rates vary, depending on

Table 1

Comparison of abalone growth between the gene-transfer (injected) group and the control (untreated) group

\begin{tabular}{lllll}
\hline & & \multicolumn{2}{c}{ Age } \\
\cline { 3 - 5 } & & 1 week & 6 months & 1 year \\
\hline Density (individuals $\left./ \mathrm{m}^{2}\right)$ & Untreated & $3.9 \pm 0.8 \times 10^{5, \mathrm{a}}$ & $2.7 \pm 0.5 \times 10^{2, \mathrm{a}}$ & $0.8 \pm 0.2 \times 10^{2, \mathrm{a}}$ \\
& Injected & $4.0 \pm 1.1 \times 10^{5, \mathrm{a}}$ & $2.8 \pm 0.7 \times 10^{2, \mathrm{a}}$ & $0.9 \pm 0.3 \times 10^{2, \mathrm{a}}$ \\
Length $(\mathrm{cm})$ & Untreated & $0.24 \pm 0.01^{\mathrm{b}}$ & $1.5 \pm 0.13^{\mathrm{b}}$ & $3.3 \pm 0.21^{\mathrm{b}}$ \\
& Injected & $0.23 \pm 0.01^{\mathrm{b}}$ & $2.2 \pm 0.22^{\mathrm{c}}$ & $4.2 \pm 0.34^{\mathrm{c}}$ \\
Weight $(\mathrm{g})$ & Untreated & - & $2.2 \pm 0.32^{\mathrm{d}}$ & $4.3 \pm 0.47^{\mathrm{d}}$ \\
& Injected & - & $3.8 \pm 0.23^{\mathrm{e}}$ & $7.8 \pm 0.72^{\mathrm{e}}$ \\
\hline
\end{tabular}

The presented data are means $\pm \mathrm{SD}$, which in the same column sharing a common superscript letter are not significantly different $(P<0.05)$. Dashes indicate that the animal was too small to weigh. 
animal species and transfer method. In shellfishes, genetransfer rates were $72 \%$ using electroporation in red abalone embryos (Powers et al., 1995), 2\% to 5\% using retroviral infection in dwarf surf clams (Lu et al., 1996), $40 \%$ with particle bombardment of the Pacific oyster (Cadoret et al., 1997a), 65\% with electroporation of abalone sperm (Tsai et al., 1997), 48\% with by microinjection and electroporation, and 20\% using chemical-mediated transfection in Eastern oyster embryos, respectively (Cadoret et al., 1997b; Buchanan et al., 2001). In this study, we used PCR-Southern analysis of the genomic DNA extracted from sperm after incubation with DNase I, which enabled the digestion of DNA that remained outside the sperm without entering. A 954-bp PCR-Southern-positive finding was the basis determining the gene-transfer efficiency. The genetransfer efficiency was not affected by what part of the testis received the injection of foreign DNA. However, a higher gene-transfer rate was obtained using a higher concentration of DNA fragments. Interestingly, the gene-transfer efficiencies we found in the 1-week trochophore larvae, 3-week-old juveniles, and 1-yearold adults were $90 \%, 92.5 \%$, and $60 \%$, respectively. Our findings are consistent with those from studies of testis injection in other animal species, including DNA injection into the vas deferens (Huguet and Esponda, 1998) and testis (Sato et al., 2002) of mouse, the testis of silkworm (Shamila and Mathavan, 1998), and the spermatophore of giant freshwater prawn ( $\mathrm{Li}$ and Tsai, 2000). Moreover, we find that the transgene is detected in the gonad of around $20 \%(60 \% \times 31-33 \%=18-19 \%)$ of surviving mature abalone of $\mathrm{G}_{0}$ derived from the DNA-injection group, suggesting that the gene transmission is easier to generate, compared to the conventional gene transfer. In addition, it is not necessary to culture the treated $\mathrm{G}_{0}$ individuals to adulthood before the transgenic founders able to transmit the transgene to offspring are identified. Therefore, we believe the direct testis-injection technique reported in this study is the highest efficiency and the most convenient of genetransfer techniques to date, although the germ-line transmission is needed for further confirmation.

Almost all transgenes present in extra-chromosomal form in transgenic animals should exhibit mosaicism and cannot generate germ-line transmission. Many attempts are reported to improve the genomic integration of the transgene in the founder individuals, such as protamine sulfate (Lechardeur et al., 1999), DNA mixed with nuclear transport peptide (Sebestyen et al., 1998; Liang et al., 2000), and DNA flanked with inverted terminal repeats from adeno-associated viruses (Fu et al., 1998; Hsiao et al., 2001). These methods do improve the transgene integration and expression in the transgenic fish. However, tedious work is needed to prepare either chemical reagents or gene constructs. Surprisingly, in this study, we find that even naked DNA fragments delivered by a direct-testis injection still have a great chance to integrate into the genome of abalone, which was demonstrated by Southern blot analysis of genomic DNA (Fig. 4). Moreover, we can find positive hybridization bands with molecular weights that are higher than that of the transferred gene in the gonad of founder individuals. Non-homologous recombination end-joining of the transgene, such as rearrangements, partial deletions, and terminal modifications, was frequent after gene transfer both in cell lines (Nakai et al., 1999) and in transgenic animals (Hsiao et al., 2001; Chou et al., 2001). In this study, our results suggested similar modifications of the transgene in the transgenic abalone.

We randomly collected 100 individuals from the DNA-injected group and found that both shell lengths and body weights of abalone were significantly higher than those of abalone from the untreated group at the same stage (Table 1). Although the mechanism of how fish growth hormone affects the growth of abalone is unclear, this evidence suggests that the transgene might be expressed and functioned, resulting in growth enhancement of transgenic abalone. Using RT-PCR to detect the YPGH mRNA or using Western blot to detect the YPGH protein in the transgenic abalone remains to further study.

Most sperm-mediated gene transfers have been performed in mammals, including mice (Spadafora, 1998; Perry et al., 1999), pigs (Farre et al., 1999), bovids (Gagne et al., 1991), and humans (Spadafora, 1998); and other vertebrates, including amphibians (Takac et al., 1998) and zebrafish (Khoo et al., 1992). Also, spermmediated gene transfer has been studied in invertebrates, including insects (Atkinson et al., 1991; Shamila and Mathavan, 1998), abalone (Tsai et al., 1997), and mussel (Kuznetsov et al., 2001). The interaction between the living spermatozoa and naked DNA fragments has been reviewed by Spadafora (1998), Gandofi (1998), and Sato et al. (2002). It is thought that the interaction between sperm cells and foreign DNA from a variety of species is regulated by specific protein factors (Lavitrano et al., 1997; Perry et al., 1999). DNA binding proteins on the membrane of spermatozoa reportedly direct the internalization of naked DNA (Zani et al., 1995; Lavitrano et al., 1997; Shamila and Mathavan, 2000). The molecular mass of the binding protein is 30 to $35 \mathrm{kDa}$ in mammals (Lavitrano et al., 1992; Zani et al., 1995), and 26 to $50 \mathrm{kDa}$ in silkworm (Shamila and 
Mathavan, 2000). The ability of animal spermatozoa to easily incorporate foreign DNA fragments may be attributed to the absence of a normal nuclear envelope (Baccetti and Afzelius, 1976) or to the character of the nuclear sperm constituents, which are different from those of the typical eukaryotic cell (Balhorn, 1982; Bedford and Hoskins, 1990). For shellfishes, the molecular mechanisms modulating the interaction between the sperm cells and foreign DNA and the internalization of the DNA are not yet understood. Nevertheless, the reason that testis injection in this study causes a high occurrence of gene transfer in abalone is the most interesting issue to be addressed. We speculate that the incubation for 3-6 h after injection greatly facilitates the entry of foreign DNA into abalone sperm. Sato et al. (2002) demonstrated that the longer the foreign plasmids remain in the spermatophore and testis, the greater the probability they will enter sperm. Further research is needed on factors affecting gene-transfer rate, including any special characteristics of abalone testis, the biology of abalone sperm, and their associated proteins.

\section{Acknowledgments}

This research was supported by the National Science Council NSC 92-2313-B002-056 (HJT), and by the Council of Agriculture 92-4.2.3-F1 (2)-3 (HJT), the Republic of China.

\section{References}

Atkinson, P.W., Hines, E.R., Beaton, S., Mattaei, K.I., Reed, K.C., Bradly, M.P., 1991. Association of exogenous DNA with cattle and insect spermatozoa in vitro. Mol. Reprod. Dev. 29, 1-5.

Baccetti, B., Afzelius, B., 1976. The biology of the sperm cell. In: Sauger, H.W. (Ed.), Monographs in Developmental Biology, vol. x. Karger Publisher, New York, p. 254.

Balhorn, R., 1982. A model for the structure of chromatin in mammalian sperm. J. Cell Biol. 93, 298-305.

Bedford, J.M., Hoskins, D.D., 1990. The mammalian spermatozoan: morphology, biochemistry and physiology. In: Marshall, F.H.A., Laming, G.E. (Eds.), Physiology of Reproduction, vol. II. Churchill Livingstone, Edinburgh, pp. 379-568.

Buchanan, J.T., Nicken, A.D., Cooper, R.K., Tiersch, T.R., 2001. Transfection of eastern oyster (Crassotrea virginica) embryos. Mar. Biotechnol. 3, 322-325.

Cadoret, J.P., Boulo, V., Gendreau, S., Miahle, E., 1997a. Promoters from Drosophila heat shock protein and cytomegalovirus drive transient expression of luciferase introduced by particle bombardment into embryos of the oyster Crassostrea gigas. J. Biotechnol. $56,183-189$.

Cadoret, J.P., Gendreau, S., Delecheneau, J.M., Rousseau, C., Miahle, E., 1997b. Microinjection of bivalve eggs: application in genetics. Mol. Mar. Biol. Biotechnol. 6, 72-77.
Chen, H.C., Yang, H.S., 1979. Artificial propagation of the abalone, Haliotis diversicolor supertexta. China Fish. Mon. 314, 3-14.

Chou, C.Y., Horng, L.S., Tsai, H.J., 2001. Uniform GFP-expression in transgenic medaka (Oryzias latipes) at the F0 generation. Transgenic Res. 10, 303-315.

Chourrout, D., Guyomard, R., Houdebine, L.M., 1986. Highefficiency gene transfer in rainbow trout (Salmo gairdneri) by microinjection into egg cytoplasm. Aquaculture 51, 143-150.

Dunham, R.A., Eash, J., Askins, J., Townes, T.M., 1987. Transfer of the metallothionein-human growth hormone fusion gene into channel catfish. Trans. Am. Fish. Soc. 116, 87-91.

Dunham, R.A., Ramboux, A.C., Duncan, P.L., Hayat, M., Chen, T.T., Lin, C.M., Knight, K., Gonzalez-Villasenor, I., Powers, D.A., 1992. Transfer, expression, and inheritance of salmonid growth hormone genes in channel catfish, Ictalurus punctatus, and effects on performance traits. Mol. Mar. Biol. Biotechnol. 1, 380-389.

Farre, L., Rigau, T., Mogas, T., Garcia-Rocha, M., Canal, M., GomezFoix, A.M., Rodriguez-Gil, J.E., 1999. Adenovirus-mediated introduction of DNA into pig sperm and offspring. Mol. Reprod. Dev. 53, 149-158.

Fletcher, G.L., Shears, M.A., King, M.J., Davies, P.L., Hew, C.L., 1988. Evidence for antifreeze protein gene transfer in Atlantic salmon (Salmo salar). Can. J. Fish. Aquat. Sci. 45, 352-357.

Fu, Y., Wang, Y., Evans, S.M., 1998. Viral sequences enable efficient and tissue specific expression of transgene in Xenopus. Nat. Biotechnol. 16, 253-257.

Gagne, M.B., Pothier, F., Sirard, M.A., 1991. Electroporation of bovine spermatozoa to carry foreign DNA in oocytes. Mol. Reprod. Dev. 29, 6-15.

Gandofi, F., 1998. Spermatozoa, DNA binding and transgenic animals. Transgenic Res. 7, 147-155.

Gong, Z., Hew, C.L., 1995. Transgenic fish in aquaculture and developmental biology. Curr. Top. Dev. Biol. 30, 177-214.

Hsiao, C.D., Hsieh, F.J., Tsai, H.J., 2001. Enhanced expression and stable transmission of transgenes flanked by inverted terminal repeats from adeno-associated virus in zebrafish. Dev. Dyn. 220, 323-336.

Huguet, E., Esponda, P., 1998. Foreign DNA introduced into the vas deferens is gained by mammalian spermatozoa. Mol. Reprod. Dev. $51,42-52$.

Inoue, K., Yamashita, S., Hata, J., Kabeno, S., Asada, S., Nagahisa, E., Fujita, T., 1990. Electroporation as a new technique for producing transgening fish. Cell Differ. Dev. 29, 123-128.

Khoo, H.W., Ang, L.H., Lim, H.B., Wong, Y., 1992. Sperm cells as vectors for introducing foreign DNA into zebrafish. Aquaculture $107,1-19$.

Kuznetsov, A.V., Pirkova, A.V., Dvoryanchikov, G.A., Panfertsev, E. A., Gavryushkin, A.V., Kuznetsova, I.V., Erkhin, V.E., 2001. Study on the transfer of foreign genes into mussel Mytilus galloprovincialis Lam. eggs by spermatozoa. Russ. J. Dev. Biol. 32, 254-262.

Lavitrano, M., French, D., Zani, M., Frati, L., Spadafora, C., 1992. The interaction between exogenous DNA and sperm cells. Mol. Reprod. Dev. 31, 161-169.

Lavitrano, M., Maione, B., Forte, E., Francolini, M., Sperandio, S., Testi, R., Spadafora, C., 1997. The interaction of sperm cells with exogenous DNA - a role of CD4 and major histocompatibility complex class II molecules. Exp. Cell Res. 233, $56-62$.

Lechardeur, D., Sohn, K.J., Haardt, M., Joshi, P.B., Monck, M., Graham, R.W., Beatty, B., Squire, J., O’Brodovich, H., Lukacs, G. 
L., 1999. Metabolic instability of plasmid DNA in the cytosol: a potential barrier to gene transfer. Gene Ther. 6, 482-497.

Li, S.S., Tsai, H.J., 2000. Transfer of foreign gene to giant freshwater prawn (Macrobrachium rosenbergii) by spermatophore-microinjection. Mol. Reprod. Dev. 56, 149-154.

Liang, M.R., Aleström, P., Collas, P., 2000. Glowing zebrafish: integration, transmission, and expression of a single luciferase transgene promoted by noncovalent DNA-nuclear transport peptide complex. Mol. Reprod. Dev. 55, 8-13.

Lu, J.K., Chen, T.T., Chrisman, C.L., Andrisani, O.M., Dixon, J.E., 1992. Integration, expression, and germ-line transmission of foreign growth hormone genes in medaka (Oryzias latipes). Mol. Mar. Biol. Biotechnol. 1, 366-375.

Lu, J.K., Chen, T.T., Allen, S.K., Matsubara, T., Burns, J.C., 1996. Production of transgenic dwarf surf clams, Mulinia lateralis, with pantropic retroviral vectors. Proc. Natl. Acad. Sci. U. S. A. 93, 3482-3486.

Muller, E., Ivics, Z., Erdelyi, F., Papp, T., Varadi, L., Horvath, L., MacLean, N., Orban, L., 1992. Introducing foreign genes into fish eggs with electroporated sperm as a carrier. Mol. Mar. Biol. Biotechnol. 1, 276-281.

Nakai, H., Iwaki, Y., Kay, M.A., Couto, L.B., 1999. Isolation of recombinant adeno-associated virus vector-cellular DNA junctions from mouse liver. J. Virol. 73, 5438-5447.

Ozato, K., Kondoh, H., Inohara, H., Iwamatsu, T., Wakamatsu, Y., Okada, T.S., 1986. Production of transgenic fish: introduction and expression of chicken delta-crystallin gene in medaka embryos. Cell Differ. 19, 234-237.

Perry, A.C.F., Wakayama, T., Kishikawa, H., Kasai, T., Okabe, M., Toyoda, Y., Yanagimachi, R., 1999. Mammalian transgenesis by intracytoplasmic sperm injection. Science 284, 1180-1183.

Powers, D.A., Hereford, L., Cole, T., Chen, T.T., Lin, C.M., Knight, K., Creech, K., Dunham, R., 1992. Electroporation: a method for transferring genes into the gametes of zebrafish (Brachydanio rerio), channel catfish (Ictalurus punctatus), and common carp (Cyprinus carpio). Mol. Mar. Biol. Biotechnol. 1, 301-308.

Powers, D.A., Kirby, V.L., Cole, T., Hereford, L., 1995. Electroporation as an effective means of introducing DNA into abalone (Haliotis rufescens) embryos. Mol. Mar. Biol. Biotechnol. 4, 369-375.

Sambrook, J., Fritsch, E.F., Maniatis, T., 1989. Large-scale preparations of plasmid DNA. Molecular cloning: a laboratory manual. Cold Spring Harbor Laboratory Press, New York, pp. 1.33-1.46.

Sato, M., Ishikawa, A., Kimura, M., 2002. Direct injection of foreign DNA into mouse testis as a possible in vivo gene transfer system via epididymal spermatozoa. Mol. Reprod. Dev. 61, 49-56.
Sebestyen, M.G., Ludtke, J.J., Bassik, M.C., Zhang, G., Budker, V., Lukhtanov, E.A., Hagstrom, J.E., Wolff, J.A., 1998. DNA vector chemistry: the covalent attachment of signal peptides to plasmid DNA. Nat. Biotechnol. 16, 80-85.

Shamila, Y., Mathavan, S., 1998. Sperm-mediated gene transfer in the silkworm Bombyx mori. Arch. Insect Biochem. Physiol. 37, $168-177$.

Shamila, Y., Mathavan, S., 2000. Sperm/DNA interaction: DNA binding proteins in sperm cell of silkworm Bombyx mori. Mol. Reprod. Dev. 56, 289-291.

Sin, F.Y.T., 1997. Transgenic fish. Rev. Fish Biol. Fish. 7, 417-441.

Spadafora, C., 1998. Sperm cells and foreign DNA: a controversial relation. BioEssays 20, 955-964.

Symonds, J.E., Walker, S.P., Sin, F.Y.T., Sin, I., 1994. Development of a mass gene transfer method in chinook salmon: optimization of gene transfer by electroporated sperm. Mol. Mar. Biol. Biotechnol. 3, 104-111.

Takac, M., Habrova, V., Macha, J., Ceskova, N., Jonak, J., 1998. Development of transgenic Xenopus laevis with a high C-src gene expression. Mol. Reprod. Dev. 50, 410-419.

Takagi, S., Sasado, T., Tamiya, G., Ozato, K., Wakamatsu, Y., Takeshita, A., Kimura, M., 1994. An efficient expression vector for transgenic medaka construction. Mol. Mar. Biol. Biotechnol. 3, 192-199.

Tsai, H.J., 2000. Electroporated sperm mediation of a gene transfer system for finfish and shellfish. Mol. Reprod. Dev. 56, 281-284.

Tsai, H.J., Tseng, F.S., 1994. Electroporation of a foreign gene into black porgy (Acanthopagrus schlegeli) embryos. Fish. Sci. 60, 787-788.

Tsai, H.J., Lin, K.L., Chen, T.T., 1993. Moleculare cloning and expression of yellowfin porgy (Acanthopagrus latus houttuyn) growth hormone cDNA. Comp. Biochem. Physiol. 104B, 803-810.

Tsai, H.J., Tseng, F.S., Liao, I.C., 1995a. Electroporation of sperm to introduce foreign DNA into the genome of loach (Misgurnus anguillicaudatus). Can. J. Fish. Aquat. Sci. 52, 776-787.

Tsai, H.J., Wang, S.H., Inoue, K., Kimura, M., Wakamatsu, Y., Ozato, K., 1995b. Initiation of the transgenic lacZ gene expressed in medaka (Oryzias latipes) embryos. Mol. Mar. Biol. Biotechnol. 4, $1-9$.

Tsai, H.J., Lai, C.H., Yang, H.S., 1997. Sperm as a carrier to introduce an exogenous DNA fragment into the oocyte of Japanese abalone (Haliotis diversicolor supertexta). Transgenic Res. 6, 85-95.

Zani, M., Larvitrano, M., French, D., Lulli, V., Maione, B., Sperandio, S., Spadafore, C., 1995. The mechanism of binding of exogenous DNA to sperm cells: factors controlling the DNA uptake. Exp. Cell Res. 217, 57-64. 